\title{
Genomic Diversity and Phylogenetic Relationships among Lipid-Requiring Diphtheroids from Humans and Characterization of Corynebacterium macginleyi sp. nov.
}

\author{
P. RIEGEL, ${ }^{1 *}$ R. RUIMY, ${ }^{2}$ D. DE BRIEL,${ }^{1}$ G. PRÉVOST, ${ }^{1}$ F. JEHL, ${ }^{1}$ R. CHRISTEN, ${ }^{2}$ AND H. MONTEIL ${ }^{1}$ \\ Institut de Bactériologie de la Faculté de Médecine, Université Louis-Pasteur, 67000 Strasbourg, ${ }^{1}$ and Centre National \\ de la Recherche Scientifique and Université PARIS VI Station Zoologique, 06230 Villefranche sur Mer, ${ }^{2}$ France
}

DNA relatedness experiments were performed with 38 clinical isolates and 13 reference strains of coryneform taxa exhibiting a lipid requirement for optimal growth. Forty-five of these strains split into five genomic groups at the species level, whereas six other strains remained unclustered. Genomospecies II fits Corynebacterium accolens, but the other genomospecies were not genetically related to any of the defined Corynebacterium species. Phylogenetic analyses of genes coding for small-subunit rRNA sequences revealed that two genomospecies (I and III) and $C$. accolens form a tight cluster within the robust branch that groups all Corynebacterium species presently sequenced. Reference strains of biotypes C-1, C-2, and C-3 of "Corynebacterium pseudogenitalium" were found to fall into genomospecies I, as well as "Corynebacterium tuberculostearicum," Centers for Disease Control and Prevention (CDC) coryneform group G-1, and CDC coryneform group G-2 reference strains. Biochemical tests allowed differentiation between genomospecies except between genomospecies IV and V and between six unclustered strains and genomospecies I. We propose a new classification for these lipid-requiring diphtheroids within the genus Corynebacterium with the delineation of some CDC coryneform group G-1 strains (genomospecies III) as a new species for which the name Corynebacterium macginleyi is proposed. The type strain is strain JCL-2 (CIP 104099), isolated from a human corneal ulcer.

Pleomorphic gram-positive rods, also known as diphtheroids, were found to be a component of the bacterial flora of certain human body sites (16). As some of these diphtheroids show a lipid requirement for growth, which can be supplied by serum or Tween 80 , these strains have often been referred to as lipophilic diphtheroids. Attempts to classify these organisms on the basis of biochemical characteristics have been undertaken. Smith (26) separated lipophilic diphtheroids isolated from the skin into seven taxonomic groups, while Furness et al. reported (9) ten phenotypic groups for such coryneform bacteria isolated from nonspecific urethritis corresponding to five pathogenic types ("Corynebacterium genitalium") and five saprophytic types ("Corynebacterium pseudogenitalium") of the urogenital tract (8). Analysis of their cell walls revealed the presence of arabinose, galactose, diaminopimelic acid, and corynomycolic acids (7), which are characteristic of the genus Corynebacterium. The Centers for Disease Control and Prevention (CDC; Atlanta, Ga.) separated lipophilic diphtheroids into groups G-1 and G-2 in addition to groups JK and D-2 (11, 23). McGinley et al. confirmed the presence of meso-diaminopimelic acid in the cell wall of lipophilic diphtheroids and found a similar composition of cellular fatty acids and of mycolic acids for all of the lipophilic diphtheroids, including group JK strains (17). At the same time, Cocito and Delville (4) recognized such strains in human leprosy lesions, which were referred to as leprosy-derived corynebacteria and tentatively delineated as "Corynebacterium tuberculostearicum." Jackman et al. (14) published the description of Corynebacterium jeikeium for CDC coryneform group JK strains, and Pitcher et al. proposed the name Corynebacterium urealyticum for CDC coryneform group D-2 in 1992 (19). Recently,

\footnotetext{
* Corresponding author. Mailing address: Institut de Bactériologie de la Faculté de Médecine, 3 rue Koeberlé, F-67000 Strasbourg, France. Phone: 33.88.21.19.70. Fax: 33.88.25.11.13.
}

nonfermenting lipophilic strains, formerly known as group ANF-1 strains, were delineated as subspecies lipophilum of a new species, Corynebacterium afermentans (21). The most reliable system of identification of lipophilic diphtheroids remains the scheme of the $\mathrm{CDC}(11)$, based on routine biochemical tests.

To determine more precisely the taxonomic status of the lipophilic diphtheroids, we studied strains isolated from various clinical specimens which exhibited heterogeneous biochemical patterns. Some additional strains were kindly provided by reference laboratories and referred to as $\mathrm{CDC}$ coryneform groups F-1, G-1 and G-2, " $C$. genitalium," " $C$. pseudogenitalium," and "C. tuberculostearicum." Determination of cell wall composition and $\mathrm{G}+\mathrm{C}$ content of DNA were performed for some of these strains to confirm their assignment to the genus Corynebacterium. DNA-DNA hybridizations by an $\mathrm{S} 1$ nuclease procedure and comparisons of genes (rDNA) coding for small-subunit rRNA sequences were used to determine the levels of genomic diversity of these lipophilic diphtheroids and their phylogenetic relationships with established Corynebacterium species. On the basis of these results, we propose a new classification for some of these strains, including the delineation of a new species, Corynebacterium macginleyi.

\section{MATERIALS AND METHODS}

Bacterial strains. We studied 38 strains isolated in our laboratory from human clinical sources (listed in Table 1) which exhibited a lipid requirement and a production of acid from glucose. In addition, 13 reference strains belonging to lipophilic taxa were included in this study. CDC coryneform group G-1 strains $F$ 8156 and F 6978, CDC coryneform group G-2 strain G 5840, and CDC coryneform group F-1 strains $\mathrm{G} 4330$ and $\mathrm{G} 5911$ were a generous gift from $\mathrm{R}$. E. Weaver, (CDC, Atlanta, Ga.). CDC coryneform group G-1 strain LCDC 81-613 was a generous gift from $\mathrm{K}$. A. Bernard, Laboratory Center for Disease Control (LCDC; Ottawa, Ontario, Canada), and " $C$. tuberculostearicum" LDC 8 (ATCC 35521) was kindly provided by C. Cocito, Faculty of Medicine, Brussels, Belgium.

The reference strains " $C$. genitalium" (CCUG 28784 [ATCC 33034] and 
TABLE 1. DNA relatedness among unnamed lipophilic diphtheroids

\begin{tabular}{|c|c|c|c|c|c|c|c|c|}
\hline \multirow{2}{*}{ Strain } & \multirow{2}{*}{ Source of strain } & \multirow{2}{*}{$\mathrm{G}+\mathrm{C}$ content $(\mathrm{mol} \%)$} & \multicolumn{5}{|c|}{$\%$ DNA relatedness at $60^{\circ} \mathrm{C}$ with indicated strain } & \multirow{2}{*}{ Genomospecies } \\
\hline & & & G 5840 & T 48462 & JCL-2 & G 4330 & $\overline{\text { G } 5911}$ & \\
\hline CDC G 5840 & Blood & 62 & 100 & & & & & I \\
\hline CDC F 8156 & Eye & 62 & 80 & & & & & I \\
\hline Т 13555 & Blood & 60 & 78 & & & & & I \\
\hline Т 42214 & Blood & 62 & 100 & & & & & I \\
\hline LDC 8 & Skin & 62 & 70 & & & & & I \\
\hline В $96869-1$ & Semen & & 69 & & & & & I \\
\hline В 31999 & Mitral valve & & 72 & & & & & I \\
\hline B 32070 & Skin & & 72 & & & & & I \\
\hline B 61905 & Abscess & & 69 & & & & & I \\
\hline В $34507-1$ & Semen & & 84 & & & & & I \\
\hline T 11394 & Blood & & 75 & & & & & I \\
\hline B $39020-1$ & Urethra & & 94 & & & & & I \\
\hline B 40064 & Abscess & & 97 & & & & & I \\
\hline B 23323 & Urethra & & 91 & & & & & I \\
\hline CCUG 28788 & Urethra & & 98 & & & & & I \\
\hline CCUG 28789 & Urethra & & 78 & & & & & I \\
\hline CCUG 28790 & Urethra & & 75 & & & & & I \\
\hline Т 48462 & Blood & 62 & 18 & 100 & & & & II \\
\hline CDC F 6978 & Blood & 62 & 9 & 76 & & & & II \\
\hline В 65591 & Nose & 63 & & 68 & & & & II \\
\hline B 94062 & Nose & 61 & & 67 & & & & II \\
\hline T 95757 & Blood & 61 & & 100 & & & & II \\
\hline B 80466 & $\begin{array}{l}\text { Tracheal } \\
\text { aspirate }\end{array}$ & 62 & & 88 & & & & II \\
\hline B 85253 & Sputum & 62 & & 94 & & & & II \\
\hline B 87715 & Sputum & 61 & & 67 & & & & II \\
\hline B 97267 & Nose & 61 & & 68 & & & & II \\
\hline В 99797 & Nose & & & 94 & & & & II \\
\hline В 714 & Nose & & & 94 & & & & II \\
\hline В 5375 & Nose & & & 80 & & & & II \\
\hline B $60371-1$ & $\begin{array}{l}\text { Cerebrospinal } \\
\text { fluid shunt }\end{array}$ & & & 76 & & & & II \\
\hline B 60377 & $\begin{array}{l}\text { Cerebrospinal } \\
\text { fluid shunt }\end{array}$ & & & 86 & & & & II \\
\hline B 51910 & $\begin{array}{l}\text { Bronchiole } \\
\text { washing }\end{array}$ & & & 100 & & & & II \\
\hline JCL-2 & Eye & 58 & 1 & 35 & 100 & & & III \\
\hline B 72932 & Eye & 58 & & & 92 & & & III \\
\hline B 38994 & Eye & & & & 96 & & & III \\
\hline CDC G 4330 & Urine & 63 & 3 & 1 & 9 & 100 & & IV \\
\hline В 15991 & Urethra & & & & & 71 & & IV \\
\hline В 1657 & Urethra & & & & & 67 & & IV \\
\hline B $11477-2$ & Urethra & & & & & 73 & & IV \\
\hline B $23320-1$ & Urethra & & & & & 78 & & IV \\
\hline CCUG 27540 & Urethra & & & & & 80 & & IV \\
\hline CDC G 5911 & Urethra & 63 & 2 & 1 & 1 & 35 & 100 & $\mathrm{~V}$ \\
\hline B 21472 & Urethra & & & & & 37 & 90 & V \\
\hline В $8702-1$ & Urethra & & & & & 37 & 78 & V \\
\hline В 9819 & Urethra & & & & & 31 & 96 & $\mathrm{~V}$ \\
\hline CCUG 28784 & Urethra & & 12 & 3 & 1 & 4 & 7 & $\mathrm{NC}^{a}$ \\
\hline CCUG 28787 & Urethra & & 12 & 14 & 20 & 16 & 6 & $\mathrm{NC}$ \\
\hline B 21118 & Urethra & & 3 & 10 & 9 & 12 & 2 & NC \\
\hline B $34507-2$ & Semen & & 22 & 20 & 15 & 8 & $1 \overline{7}$ & $\mathrm{NC}$ \\
\hline B 23321 & Vagina & & 10 & 8 & 9 & 24 & 1 & $\mathrm{NC}$ \\
\hline LCDC 81-613 & Bile & & 6 & 2 & 14 & 1 & 1 & NC \\
\hline \multicolumn{9}{|l|}{ Corynebacterium species } \\
\hline C. accolens CCUG $28779^{\mathrm{T}}$ & & & 11 & 85 & 25 & 8 & 6 & \\
\hline C. diphtheriae CIP $100721^{\mathrm{T}}$ & & & 1 & 4 & 5 & 16 & 5 & \\
\hline C. jeikeium CIP $103337^{\mathrm{T}}$ & & & 1 & 2 & 1 & 9 & 1 & \\
\hline C. urealyticum ATCC $43042^{\mathrm{T}}$ & & & 9 & 7 & 1 & 7 & 2 & \\
\hline
\end{tabular}

${ }^{a} \mathrm{NC}$, not clustered. 
CCUG 28786 [ATCC 33031]) and " $C$. pseudogenitalium" (CCUG 28787 [ATCC 33035], CCUG 28788 [ATCC 33036], CCUG 28789 [ATCC 33037], CCUG 28790 [ATCC 33038], and CCUG 27540 [ATCC 33039]) were kindly supplied by E. Falsen, Culture Collection of the University of Göteborg (CCUG), Sweden. The type strains of Corynebacterium species were obtained from the CCUG, the Collection of the Institut Pasteur (CIP), and the American Type Culture Collection (ATCC).

Growth conditions and biochemical tests. Bacteria were grown aerobically at $37^{\circ} \mathrm{C}$ on trypticase soy agar (bioMérieux, Marcy-l'Etoile, France) supplemented with $5 \%$ (vol/vol) sheep blood and on the same medium with the addition of $1 \%$ (vol/vol) Tween 80 (polyoxyethylene sorbitan mono-oleate; Merck, Darmstadt Germany). The lipid requirement was determined by comparison of growth in brain heart infusion (bioMérieux) after $72 \mathrm{~h}$ at $37^{\circ} \mathrm{C}$ with and without supplement of Tween 80 . The API-Coryne system was used according to the manufacturer's instructions (bioMérieux) except for the time of incubation which was fixed at $48 \mathrm{~h}$. Acidification from fructose was determined as previously described (20). DNase was tested on plates containing agar supplemented with $1 \%$ ( $\mathrm{vol} / \mathrm{vol}$ ) Tween 80 after incubation for 5 days at $37^{\circ} \mathrm{C}$. Tests of degradation of gelatin and tyrosine were performed in nutrient plate culture. Arginine dihydrolase was detected by using Moeller's base overlaid with sterile mineral oil

Cell wall analysis. Amino acid and sugar determinations were carried out by thin-layer chromatography according to the procedure of Staneck and Roberts (28). Reverse-phase high-performance liquid chromatography (HPLC) was performed for the determination of mycolic acids (6)

DNA-DNA hybridization. DNA was extracted as described previously (20), except that $10 \mu \mathrm{g}$ of proteinase $\mathrm{K}$ (Sigma) per $\mathrm{ml}$ were added to the lysozymetreated bacteria in association with $20 \mathrm{mg}$ of sodium dodecyl sulfate. Hybridization experiments between labeled DNA and fragmented DNA preparations (previously standardized in the $0.5-$ to $1-\mathrm{kb}$ range by agarose gel electrophoresis) were carried out at $60^{\circ} \mathrm{C}$ for $16 \mathrm{~h}$ in $0.42 \mathrm{M} \mathrm{NaCl}$ by the $\mathrm{S} 1$ nucleasetrichloroacetic acid method $(10,20)$.

DNA base composition determination. After extraction and purification on cesium chloride gradients, DNA was hydrolyzed with DNase I and nuclease P1, and the moles percent $\mathrm{G}+\mathrm{C}$ was determined by chromatography (HPLC) of the deoxynucleotides as described elsewhere (22).

PCR amplification and small-subunit rDNA sequencing. One hundred nanograms of DNA was used in a PCR to amplify the small-subunit rDNA sequences. A pair of primers corresponding respectively to positions 8 to 28 and 1491 to 1508 of the Escherichia coli small-subunit rDNA sequence was used. Amplifications were carried out in a reaction volume of $50 \mu \mathrm{l}$ containing $2 \mathrm{ng}$ of each primer per $\mu \mathrm{l}, 250 \mu \mathrm{M}$ deoxynucleotide triphosphates, $10 \mathrm{mM}$ Tris- $\mathrm{HCl}(\mathrm{pH} 8.8)$, $50 \mathrm{mM} \mathrm{KCl}, 1.5 \mathrm{mM} \mathrm{MgCl} 2,0.001 \%$ (wt/vol) gelatin, and $2.5 \mathrm{U}$ of Taq DNA polymerase (Stratagene Cloning Systems, La Jolla, Calif.). The procedures for PCR amplification and sequencing of PCR products were as described previously (24).

Phylogenetic analysis. The phylogenetic data described below were obtained (i) by using successive alignment and phylogeny procedures and (ii) by reinvestigating deep branching patterns after close relationships were determined (24). A neighbor-joining method (25) was used for a preliminary analysis; resulting topologies were then further investigated by maximum-likelihood and maximumparsimony methods. Maximum-likelihood analyses used the fdnaml program rewritten by G. J. Olsen (University of Illinois, Urbana, Ill.) and compiled on a Hewlett-Packard model 700 workstation, while maximum-parsimony analyses were performed with the PAUP program for the Macintosh (29). The robustness of each topology was evaluated under maximum parsimony through 100 bootstrap replications (heuristic search). Trees were plotted with the njplot program for the Macintosh computer developed by M. Gouy (URA 243 CNRS, Universite Claude Bernard, Lyon, France), which allows the transformation of a formal tree representation (Newick's format) into MacDraw drawings. Only topologies that were found to be similar by all three methods were retained as "true trees". Recent theoretical works have indeed demonstrated that convergence of the results of all three methods is an excellent indication that the correct phylogeny has been determined $(12,15)$.

Nucleotide sequence accession numbers. Sequences have been deposited in the EMBL sequence database under accession numbers X80498 (strain G 5840), X80499 (strain JCL-2), and X80500 (Corynebacterium accolens CCUG $28779^{\mathrm{T}}$ ).

\section{RESULTS}

DNA similarities. As shown in Table 1, DNA relatedness values clearly demonstrate a genomic heterogeneity among the lipid-requiring diphtheroids studied. Of the 51 strains, 45 were found to constitute five genomic groups (from I to $\mathrm{V}$ ) exhibiting internal binding values greater than $65 \%$ and lower degrees of intergroup similarity (range, 1 to $37 \%$ ). They can therefore be considered as genomospecies as defined by Brenner et al. (3). The reference strains of " $C$. pseudogenitalium" type C-2 (CCUG 28788), type C-3 (CCUG 28789), and type C-4 (CCUG 28790) belong to genomospecies I, and the reference strain of " $C$. pseudogenitalium" type C-5 (CCUG 27540 ) belongs to genomospecies IV. The strain LDC-8 (" $C$. tuberculostearicum") is included in genomospecies I. Each of the six nonclustered strains including the reference strain of "C. genitalium" type V (CCUG 28784) and "C. pseudogenitalium" type C-1 (CCUG 28787) showed less than $24 \%$ DNA similarity with any other bacteria. In order to compare the genomospecies with named Corynebacterium species, we have determined the levels of DNA relatedness between representative strains of each genomospecies and the type strains of some defined Corynebacterium species. The labeled DNA of strain T 48462, representative of genomospecies II, hybridized only with DNA from the type strain of $C$. accolens at the species level (85\%). No significant DNA relatedness was found between other genomospecies and any of the named Corynebacterium species, C. amycolatum, $C$. diphtheriae, C. jeikeium, C. minutissimum, C. pilosum, C. propinquum, C. pseudodiphtheriticum, $C$. renale, $C$. striatum, and $C$. urealyticum.

Phylogenetic analysis. General phylogenetic analyses confirmed that all Corynebacterium species belong to the high$\mathrm{G}+\mathrm{C}$ gram-positive subgroup of the Eubacteria (data not shown). All available sequences of Corynebacterium species (including our data) were grouped in a robust monophyletic unit (Fig. 1) corresponding to the genus Corynebacterium. The two lipid-requiring strains G5840 and JCL-2 formed a monophyletic cluster with $C$. accolens within the genus Corynebacterium (by all methods). The robustness of this cluster was supported by bootstrap analysis at a confidence level of $100 \%$. These three strains had rDNA sequence similarities of $97 \%$ or greater, whereas similarities lower than $95 \%$ were found with all other Corynebacterium species (Table 2).

Phenotypic characterization. All of the lipid-requiring diphtheroids studied exhibited good growth in brain heart infusion supplemented with $1 \%$ Tween 80 , in contrast with an absence of visible culture in nonsupplemented broth. This observation is in agreement with the results of McGinley et al. (17), who demonstrated a strict nutritional requirement for lipid for both lipophilic diphtheroids and $C$. jeikeium strains. Thus, the term lipid requiring seems more appropriate than the term lipophilic to describe these strains. On $1 \%$ Tween 80 -supplemented sheep blood agar, large colonies (diameter, 2 to $4 \mathrm{~mm}$ ) are observed in $48 \mathrm{~h}$, whereas very small colonies appear on sheep blood agar alone. The type strain of $C$. accolens was also found to exhibit such a lipid requirement.

Biochemical profiles obtained by using the API-Coryne system produced various identifications within a single genomospecies, while some strains remained unidentified according to the database of this procedure. All of the strains studied produced acid from glucose, in contrast to the other lipidrequiring species $C$. urealyticum and $C$. afermentans subsp. lipophilum. Genomospecies I (17 strains) included both nitrate-reducing strains identified as Corynebacterium xerosis and non-nitrate-reducing strains identified as CDC group G-2, $C$. minutissimum, or $C$. jeikeium. Strains of this genomospecies which were assigned to $C$. jeikeium exhibited a positive fructose fermentation test and growth under anaerobic conditions, which differentiate them from true $C$. jeikeium strains (20). Strains of genomospecies II (15 strains) exhibited biochemical features in agreement with the description of $C$. accolens (18), e.g., presence of nitrate reductase but lack of alkaline phosphatase and fermentation of sucrose that occurs variably in these strains. Strains of genomospecies III (3 strains) show a typical biochemical pattern among them with presence of nitrate reductase and alkaline phosphatase and lack of pyrazinamidase, pyrrolydonylarylamidase, and urease. These strains produced acid from sucrose but not from maltose. It should be 


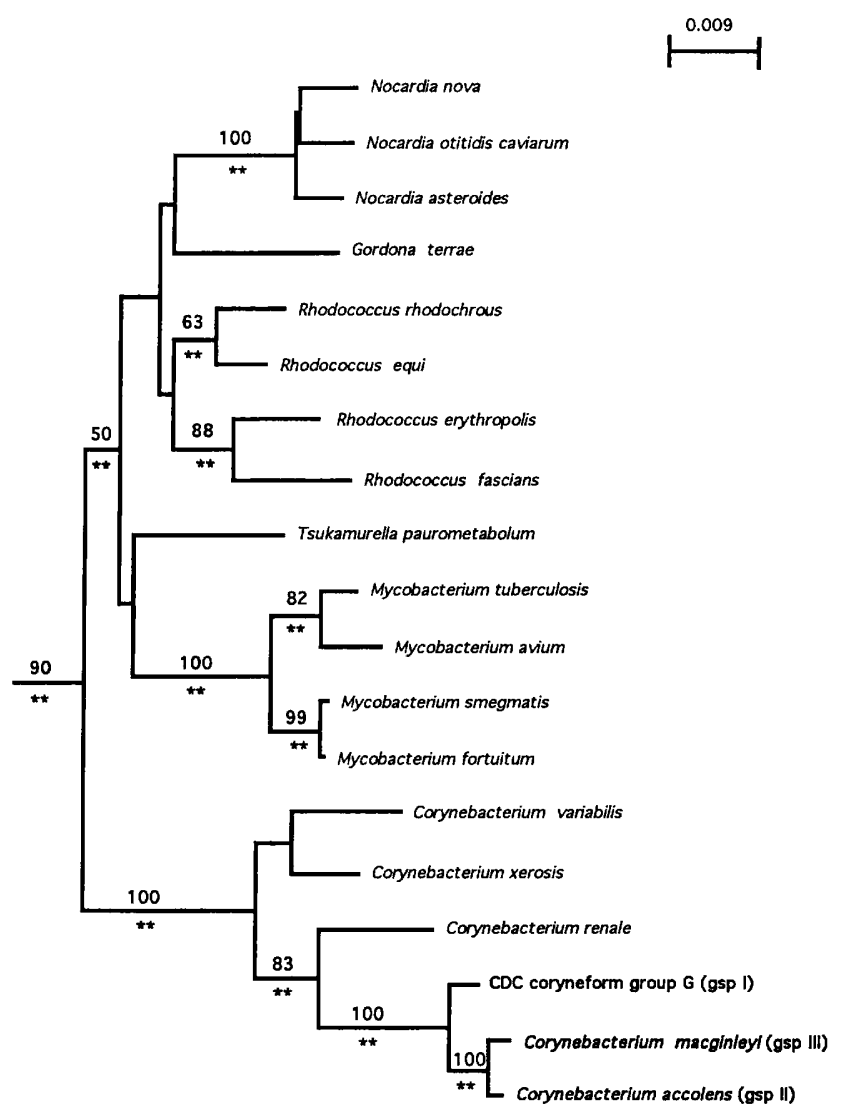

FIG. 1. Phylogenetic position of Conynebacterium species within the high$\mathrm{G}+\mathrm{C}$ gram-positive subgroup of the Eubacteria. A rooted tree summarizing the results of phylogenetic analyses by three different methods based on the comparison of small-subunit rDNA sequences of Corynebacterium species and of bacteria representative of the different genera composing the high- $G+C$ grampositive subgroup is shown. The topology shown is part of a tree obtained by a neighbor-joining method. The double asterisks indicate branches that were also found by maximum-likelihood method $(P<0.01)$. The values, expressed as percentages of bootstrap replications above the lines (only values greater than $50 \%$ are shown), show branches also found in the most parsimonious tree and supported by a bootstrap analysis (heuristic search). The scale bar represents accumulated changes per nucleotide. Domains used for these analyses correspond to positions 126 to 138,141 to 180,232 to 417,422 to 440,492 to 600,618 to 836,881 to 928,932 to 998,1040 to 1131,1137 to 1250,1265 to 1283 , and 1286 to 1355 (numbers related to $E$. coli).

noted that some strains of $C$. accolens and genomospecies III produce acid from mannitol; this is rarely encountered in the genus Corynebacterium. Genomospecies IV and V contained urease-positive strains which possess all of the biochemical features of CDC coryneform group F-1 as described by Hollis and Weaver (11). "C. pseudogenitalium" type C-5 can be assigned to this taxon. Unfortunately, these two genomospecies could not be clearly distinguished from each other by phenotypic tests, and results obtained by using API-50CH and API-Zym systems were also not conclusive (data not shown). The six strains not clustered in any genomospecies exhibited biochemical profiles similar to that of genomospecies I. Therefore, only genomospecies II (C. accolens) and genomospecies III can be phenotypically individualized. The results are summarized in Table 3.

Finally, this study indicates a specificity of habitat for each lipid-requiring diphtheroid genomospecies. Therefore, strains of genomospecies I, including a reference strain of " $C$. tuberculostearicum," seem to be inhabitants of the skin or of the
TABLE 2. Similarity matrix based on small-subunit rDNA sequences part 29 to 1387

\begin{tabular}{|c|c|c|c|c|c|}
\hline \multirow[b]{2}{*}{ Organism $^{a}$} & \multicolumn{5}{|c|}{ \% Similarity with: } \\
\hline & 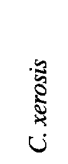 & 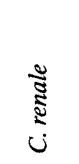 & 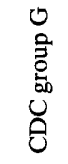 & 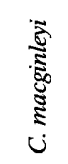 & 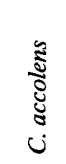 \\
\hline C. variabilis (X53185) & 95.1 & 94.2 & 93.7 & 94.0 & 94.1 \\
\hline C. xerosis (M59058) & & 93.3 & 93.5 & 93.2 & 92.8 \\
\hline C. renale (M29553) & & & 95.0 & 94.5 & 94.6 \\
\hline CDC coryneform group G (X80498) & & & & 97.1 & 98.3 \\
\hline C. macginleyi (X80499) & & & & & 98.7 \\
\hline
\end{tabular}

${ }^{a}$ Available sequences were retrieved from the EMBL database under the accession numbers indicated.

urinary tract whereas strains of genomospecies II (C. accolens) are mainly isolated from the respiratory tract. Genomospecies III contains three strains isolated from eye specimens, and genomospecies IV and V consist of urease-positive strains isolated from the urinary tract, as was reported for CDC coryneform group F-1 strains.

\section{DISCUSSION}

Our study reveals a genomic heterogeneity among unnamed lipid-requiring diphtheroids, which form at least five genomospecies according to the generally accepted criteria defining a species (27). Considering our analysis of small-subunit rDNA sequences, genomospecies I, II, and III constitute a tight cluster within the monophyletic taxa formed by other Corynebacterium species. More detailed phylogenetic analyses including representatives of all genomospecies are now necessary to correlate these analyses with the lipid requirement feature and the similarities in fatty acid and mycolic acid composition previously found for these organisms $(2,17)$. Indeed, similarity between genomospecies II and $C$. accolens is surprising since a lipid requirement was not reported for the latter. $C$. accolens was described for strains exhibiting satellitism growth near Staphylococcus aureus (18), and our data led us to investigate this feature for other lipid-requiring strains. We obtained similar observations, with a significant increase of growth near cultures of $S$. aureus.

The biochemical characteristics of the genomospecies are not well correlated with the traditional scheme of identification provided by the CDC (11). Thus, the presence of nitrate

TABLE 3. Differential characteristics ${ }^{a}$ of lipid-requiring diphtheroid genomospecies

\begin{tabular}{|c|c|c|c|c|c|c|}
\hline \multirow{3}{*}{$\begin{array}{l}\text { Genomospecies } \\
\text { (no. of strains) }\end{array}$} & \multicolumn{6}{|c|}{$\begin{array}{c}\% \text { Positive reactions for the indicated biochemical } \\
\text { characteristic }\end{array}$} \\
\hline & \multirow{2}{*}{$\begin{array}{l}\text { Nitrate } \\
\text { reductase }\end{array}$} & \multirow{2}{*}{$\begin{array}{l}\text { Pyrazin- } \\
\text { amidase }\end{array}$} & \multirow{2}{*}{$\begin{array}{l}\text { Alkaline } \\
\text { phosphatase }\end{array}$} & \multirow{2}{*}{ Urease } & \multicolumn{2}{|c|}{ Acid from: } \\
\hline & & & & & Maltose & Sucrose \\
\hline I (17) & 18 & 100 & 100 & 0 & 59 & 76 \\
\hline II (15) & 100 & 53 & 0 & 0 & 7 & 40 \\
\hline III (3) & 100 & 0 & 100 & 0 & 0 & 100 \\
\hline IV (6) & 40 & 100 & 0 & 100 & 100 & 100 \\
\hline$V(4)$ & 100 & 100 & 0 & 100 & 100 & 100 \\
\hline $\begin{array}{r}\text { Unclustered } \\
\text { strains (6) }\end{array}$ & 50 & 100 & 100 & 0 & 33 & 66 \\
\hline
\end{tabular}

${ }^{a}$ Data obtained by using the API-Coryne system. 
TABLE 4. Characteristics ${ }^{a}$ used for differentiation of $C$. macginleyi from other Conynebacterium species and related organisms

\begin{tabular}{|c|c|c|c|c|c|c|c|c|}
\hline \multirow{3}{*}{ Organism } & \multicolumn{8}{|c|}{ Value for the indicated characteristic ${ }^{b}$} \\
\hline & \multirow{2}{*}{ Lipid requirement } & \multirow{2}{*}{ Urease } & \multirow{2}{*}{ Nitrate reductase } & \multirow{2}{*}{ Pyrazinamidase } & \multirow{2}{*}{ Alkaline phosphatase } & \multicolumn{3}{|c|}{ Acid from: } \\
\hline & & & & & & Glucose & Sucrose & Maltose \\
\hline C. macginleyi & + & - & + & - & + & + & + & - \\
\hline C. accolens & + & - & + & $\mathbf{v}$ & - & + & $\mathrm{v}$ & - \\
\hline $\begin{array}{l}\text { C. afermentans subsp. } \\
\text { afermentans }\end{array}$ & - & - & - & + & + & - & - & - \\
\hline $\begin{array}{l}\text { C. afermentans subsp. } \\
\text { lipophilum }\end{array}$ & + & - & - & + & + & - & - & - \\
\hline C. amycolatum ${ }^{c}$ & - & $\mathrm{v}$ & $\mathrm{v}$ & + & + & + & $\mathrm{v}$ & $\mathrm{v}$ \\
\hline C. bovis ${ }^{d}$ & + & - & - & $\mathrm{v}$ & + & + & - & - \\
\hline C. diphtheriae & - & - & $\mathrm{v}$ & - & - & + & - & + \\
\hline C. jeikeium ${ }^{e}$ & + & - & - & + & + & + & - & - \\
\hline C. minutissimum & - & - & - & + & + & + & + & + \\
\hline C. propinquum & - & - & + & $\mathrm{v}$ & $\mathrm{v}$ & - & - & - \\
\hline C. pseudodiphtheriticum & - & + & + & + & $\mathrm{v}$ & - & - & - \\
\hline C. pseudotuberculosis & - & + & $\mathrm{v}$ & - & $\mathrm{v}$ & + & $\mathrm{v}$ & + \\
\hline C. renale & - & + & - & + & - & + & - & $\mathrm{v}$ \\
\hline C. striatum & - & - & + & + & + & + & + & - \\
\hline C. urealyticum & + & + & - & + & $\mathrm{v}$ & - & - & - \\
\hline C. xerosis & - & - & + & + & + & + & + & + \\
\hline CDC group $\mathrm{G}$ & + & - & $\mathrm{v}$ & + & + & + & $\mathrm{v}$ & $\mathrm{v}$ \\
\hline CDC group F-1 & + & + & $\mathrm{v}$ & + & - & + & + & + \\
\hline
\end{tabular}

${ }^{a}$ Data are from the API-Coryne system database and our observations.

${ }^{b}+, 90 \%$ or more of strains positive;,$- 10 \%$ or fewer of strains positive; $v, 11$ to $89 \%$ of strains positive.

${ }^{c} C$. amycolatum strains are characterized by lack of mycolic acids.

${ }^{d} C$. bovis is differentiated from $C$. jeikeium and $\mathrm{CDC}$ coryneform group $\mathrm{G}$ by the presence of $\beta$-galactosidase activity.

${ }^{e} C$. jeikeium strains are differentiated from strains of CDC coryneform group $\mathrm{G}$ by the lack of growth under anaerobic conditions.

reductase differentiating $\mathrm{CDC}$ group $\mathrm{G}-1$ from $\mathrm{CDC}$ group G-2 was noted for strains belonging to various genomospecies, whereas nitrate-reducing strains and non-nitrate-reducing strains are included in a single genomospecies. In addition, sucrose-nonfermenting strains not described in CDC coryneform taxa are associated with sucrose-fermenting strains in the same genomospecies. We found here that lipid-requiring CDC group F-1 strains belong to two different genomospecies. The two biotypes of " $C$. genitalium" that have been studied are genomically distinct, and three of the five biotypes of " $C$. pseudogenitalium" fall into a single genomospecies, which partially confirms previous data from Imaeda et al. (13). A reference strain of " $C$. tuberculostearicum," a species described for strains isolated from leprosy lesions, is included in a genomospecies formed by strains frequently found on the human skin. Thus, its implication in leprosy disease remains to be determined. Identification of lipid-requiring diphtheroids at the species level seems important for their clinical relevance, since the habitat preferences observed in this study for each genomospecies might reveal the sources of systemic infections such as endocarditis or meningitides $(1,5)$. As shown in Table 3 , only the strains of genomospecies II (C. accolens) and genomospecies III can be clearly differentiated phenotypically from other lipid-requiring diphtheroids. Therefore, genomospecies III constitutes a new species within the genus Corynebacterium, for which the name $C$. macginleyi is proposed. Table 4 shows the characteristics of this species, allowing its identification among medically relevant Corynebacterium species. Other glucose-fermenting lipid-requiring strains which do not hydrolyze urea should be grouped together as CDC coryneform group $\mathrm{G}$, since differentiation into CDC group G-1 and CDC group G-2 was found not to be valid. These strains differ from $C$. jeikeium by a positive fructose fermentative test and growth under anaerobic conditions. For urease-positive lipidrequiring strains which ferment glucose, we believe that their designation as CDC coryneform group F-1 should be maintained since they exhibit all biochemical characteristics of this taxon as described previously $(5,11)$.

Description of Corynebacterium macginleyi sp. nov. Corynebacterium macginleyi (mac.gin'ley.i. NL. gen.n. of MacGinley, name in honor of Kenneth John McGinley, who made important contributions to the knowledge of lipid-requiring diphtheroids). The description is based on the data for the three strains included in this study.

Bacteria are nonmotile pleomorphic rods, non-spore forming, and gram positive with occasionally metachromatic granules arranged in palisades or V-shaped forms. They are not acid fast, the rod-coccus cycle is absent, and they are catalase positive, oxidase negative, and facultatively anaerobic. There is no growth in brain heart infusion broth after $72 \mathrm{~h}$ at $37^{\circ} \mathrm{C}$, but growth is visible after $24 \mathrm{~h}$ in the same broth supplemented with 0.01 to $1 \%$ Tween 80 . Very small (less than $1 \mathrm{~mm}$ in diameter) and non- $\beta$-hemolytic colonies appear after $48 \mathrm{~h}$ on sheep blood agar, but on $1 \%$ Tween 80 -supplemented sheep blood agar reddish-beige colonies are large ( 2 to $4 \mathrm{~mm}$ in diameter) and Tween esterase activity is noted. Nitrate is reduced to nitrite. Acid is produced from D-glucose, ribose, and sucrose but not from maltose, lactose, D-xylose, trehalose, or glycogen. Fermentation of D-mannitol occurs variably. Tyrosine, gelatin, starch, and urea are not degraded or hydrolyzed. Esculin is not hydrolyzed. DNA is degraded. Hydrolysis of hippurate is variable. Arginine is not degraded. Cells produce alkaline phosphatase, but pyrazinamidase, pyrrolidonyl, arylamidase, $\beta$-glucuronidase, $\beta$-galactosidase, $\alpha$-glucosidase, and $N$-acetyl- $\beta$-glucosaminidase are not produced. The cell wall contains meso-diaminopimelic acid, arabinose, and galactose. Mycolic acids of short chain lengths $\left(\mathrm{C}_{26}\right.$ to $\left.\mathrm{C}_{36}\right)$ are present. DNA base composition is $58 \mathrm{~mol} \% \mathrm{G}+\mathrm{C}$ (HPLC procedure). C. macginleyi strains were isolated from human eye specimens. The type strain is strain JCL-2 (CIP 104099). It 
was isolated in Sarrebourg, France, from the eye of a patient suffering from a corneal ulcer. This strain has all the above properties for the species. Acid is produced from D-mannitol, and hippurate is hydrolyzed.

\section{ACKNOWLEDGMENTS}

We are grateful to K. A. Bernard, C. Cocito, E. Falsen, and R. E. Weaver for supplying strains, and we thank $\mathbf{H}$. G. Trüper for advice concerning the Latin name. We also thank B. Muller for microbiological assistance.

\section{REFERENCES}

1. Austin, G. A., and E. D. Hill. 1983. Endocarditis due to Corynebacterium CDC group G2. J. Infect. Dis. 147:1106.

2. Bernard, K. A., M. Bellefeuille, and E. P. Ewan. 1991. Cellular fatty acid composition as an adjunct to the identification of asporogenous, aerobic gram-positive rods. J. Clin. Microbiol. 29:83-89.

3. Brenner, D. J., P. A. D. Grimont, A. G. Steigerwalt, G. R. Fanning, E. Ageron, and C. F. Riddle. 1993. Classification of citrobacteria by DNA hybridization: designation of Citrobacter farmeri sp. nov., Citrobacter youngae sp. nov., Citrobacter braakii sp. nov., Citrobacter werkmanni sp. nov., Citrobacter sedlakii sp. nov., and three unnamed Citrobacter genomospecies. Int. J. Syst. Bacteriol. 43:645-658.

4. Cocito, C., and J. Delville. 1985. Biological, chemical, immunological, and staining properties of bacteria isolated from tissues of leprosy patients. Eur. J. Epidemiol. 1:202-231.

5. Coyle, M. B., and B. A. Lipsky. 1990. Coryneform bacteria in infectious diseases: clinical and laboratory aspects. Clin. Microbiol. Rev. 3:227-246.

6. De Briel, D., F. Couderc, P. Riegel, F. Jehl, and R. Minck. 1992. Highperformance liquid chromatography of corynomycolic acids as a tool in identification of Corynebacterium species and related organisms. J, Clin. Microbiol. 30:1407-1417.

7. Evangelista, A. T., A. Saha, M. P. Lechevalier, and G. Furness. 1978. Analysis of the cell wall constituents of Corynebacterium genitalium. Int. J. Syst. Bacteriol. 28:344-348.

8. Furness, G., and A. T. Evangelista. 1978. A diagnostic key employing biological reactions for differentiating pathogenic Corynebacterium genitalium (NSU corynebacteria) from commensals of the urogenital tract. Invest. Urol. 16:1-4.

9. Furness, G., M. H. Kamat, Z. Kaminski, and J. J. Seebode. 1971. Isolation of corynebacteria from non-specific urethritis. J. Urol. 106:557-561.

10. Grimont, P. A. D., M. Y. Popof, F. Grimont, C. Coynault, and M. Lemelin. 1980. Reproducibility and correlation study of three deoxyribonucleic acid hybridization procedures. Curr. Microbiol. 4:325-330.

11. Hollis, D. G., and R. E. Weaver. 1981. Gram-positive organisms: a guide to identification. Special Bacteriology Section, Centers for Disease Control, Atlanta.

12. Huelsenbeck, J. P., and D. M. Hillis. 1992. Success of phylogenetic methods in the four-taxon case. Syst. Biol. 42:247-264.

13. Imaeda, T., K. M. Coppola, and G. Furness. 1985. Deoxyribonucleic acids of Corynebacterium genitalium and Conynebacterium pseudogenitalium: their genome molecular weights, base ratios, and DNA relatedness with other corynebacteria involved in urinary tract infections. Can. J. Microbiol. 31: 1068-1070.

14. Jackman, P. J. H., D. G. Pitcher, S. Pelczynska, and P. Borman. 1987. Classification of corynebacteria associated with endocarditis (group JK) as Conynebacterium jeikeium sp. nov. Syst. Appl. Microbiol. 9:83-90.

15. Kim, J. 1993. Improving the accuracy of phylogenetic estimation by combining different methods. Syst. Biol. 42:331-340.

16. Leyden, J. J., K. J. McGinley, E. Hölzle, J. N. Labows, and A. M. Kligman. 1981. The microbiology of the human axilla and its relationship to axillary odor. J. Invest. Dermatol. 77:413-416.

17. McGinley, K. J., J. N. Labows, J. M. Zechman, K. M. Nordstrom, G. F. Webster, and J. J. Leyden. 1985. Analysis of cellular components, biochemical reactions, and habitat of human cutaneous lipophilic diphtheroids. J. Invest. Dermatol. 85:374-377.

18. Neubauer, M., J. Sourek, M. Ryc, J. Bohacek, M. Mara, and J. Mnukova. 1991. Conynebacterium accolens sp. nov., a Gram-positive rod exhibiting satellitism, from clinical material. Syst. Appl. Microbiol. 14:46-51.

19. Pitcher, D., A. Soto, F. Soriano, and P. Valero-Guillén. 1992. Classification of coryneform bacteria associated with human urinary tract infection (group D2) as Corynebacterium urealyticum sp. nov. Int. J. Syst. Bacteriol. 42:178181.

20. Riegel, P., D. de Briel, G. Prévost, F. Jehl, and H. Monteil. 1994. Genomic diversity among Conynebacterium jeikeium strains and comparison with biochemical characteristics and antimicrobial susceptibilities. J. Clin. Microbiol. 32:1860-1865.

21. Riegel, P., D. de Briel, G. Prévost, F. Jehl, H. Monteil, and R. Minck. 1993. Taxonomic study of Conynebacterium group ANF-1 strains: proposal of Corynebacterium afermentans $\mathrm{sp}$. nov. containing the subspecies $C$. afermentans subsp. afermentans subsp. nov. and C. afermentans subsp. lipophilum subsp. nov. Int. J. Syst. Bacteriol. 43:287-292.

22. Riegel, P., P. A. D. Grimont, D. de Briel, E. Ageron, F. Jehl, M. Pelegrin, H. Monteil, and R. Minck. 1992. Corynebacterium group D-2 ("Corynebacterium urealyticum") constitutes a new genomic species. Res. Microbiol. 143:307313.

23. Riley, P. S., D. G. Hollis, G. B. Utter, R. E. Weaver, and C. N. Baker. 1979. Characterization and identification of 95 diphtheroid (group JK) cultures isolated from clinical specimens. J. Clin. Microbiol. 9:418-424.

24. Ruimy, R., V. Breittmayer, P. Elbaze, B. Lafay, O. Boussemart, M. Gauthier and R. Christen. 1994. Phylogenetic analysis and assessment of the genera Vibrio, Photobacterium, Aeromonas, and Plesiomonas deduced from smallsubunit rRNA sequences. Int. J. Syst. Bacteriol. 44:416-426.

25. Saitou, N., and M. Nei. 1987. The neighbor-joining method: a new method for reconstructing phylogenetic trees. Mol. Biol. Evol. 4:406-425.

26. Smith, R. F. 1969. Characterization of human cutaneous lipophilic diphtheroids. J. Gen. Microbiol. 55:433-443.

27. Stackebrandt, E., and B. M. Goebel. 1994. Taxonomic note: a place for DNA-DNA reassociation and 16S rRNA sequence analysis in the present species definition in bacteriology. Int. J. Syst. Bacteriol. 44:846-849.

28. Staneck, J. L., and G. D. Roberts. 1974. Simplified approach to identification of aerobic actinomycetes by thin-layer chromatography. Appl. Microbiol. 28:226-231.

29. Swofford, D. 1990. PAUP: phylogenetic analysis using parsimony, version 3.0. Computer program distributed by the Illinois Natural History Survey, Champaign, Ill. 